\title{
INTERAKSI KEBIJAKAN PERIKANAN TANGKAP DAN KEARIFAN LOKAL DI PERAIRAN UTARA ACEH
}

\author{
Interaction Of Fishery Policy And Local Wisdom In Northen Aceh \\ Oleh: \\ Rahmat Rizqi ${ }^{*}$, Domu Simbolon ${ }^{2}$, Mustaruddin ${ }^{2}$ \\ ${ }^{1}$ Mahasiswa Program Studi Teknologi Perikanan Laut \\ ${ }^{2}$ Staf Pengajar Program Studi Teknologi Perikanan Laut \\ *Korespondensi: iqbaldayat91@gmail.com
}

\begin{abstract}
ABSTRAK
Hukum adat laot merupakan bentuk kearifan lokal yang tumbuh dari komunitas masyarakat Aceh. Kearifan lokal dalam bentuk hukum adat laot seisinya tidak bertentangan dengan kebijakan pemerintah daerah. Penelitian ini bertujuan untuk menganalisis hubungan hukum adat laot dengan kebijakan pemerintah dan Menentukan strategi pemanfaatan kawasan penangkapan ikan berbasis kearifan lokal. Analisis metode penelitian ini menggunakan deskriptif dan SWOT. Hasil penelitian menunjukkan bahwa Panglima Laot sebagai otoritas hukum / kearifan lokal mendapatkan pengakuan hukum positif dari pemerintah pusat dan pemerintah daerah. Hukum adat laot / kearifan lokal di perairan utara Aceh memiliki peran utama dalam mewujudkan pembangunan perikanan berkelanjutan karena dalam nilai-nilai kearifan lokal mengandung banyak unsur perikanan dan tangkapan yang ramah lingkungan. Strategi kebijakan perikanan tangkap berbasis kearifan lokal adalah peningkatan kapasitas kelembagaan Panglima Laot sebagai pemangku adat Laot (kearifan lokal), serta pengembangan kapal perikanan dan alat penangkap ikan yang efisien, efektif, dan ramah lingkungan.
\end{abstract}

Kata kunci: hukum adat laot, kebijakan, strategi.

\begin{abstract}
Customary law is a form of local wisdom that grows from the community of Aceh. Local wisdom in the form of adat laot law in its entirety does not conflict with local government policy. This study was Analyzing the linkage of customary law of laot with government policy and Determine the strategy of utilization of local wisdom based fishing area. Analyze methods of this research use descriptive and SWOT. The result showed that Panglima Laot as traditional law authority/local wisdom Get positive legal recognition from central government and local government. Law of adat laot / local wisdom in Aceh and especially in Aceh's northern waters play a major role in realizing sustainable fisheries development because in the values of local wisdom contains many elements of fisheries and environmentally sustainable catch. The strategy of capture fisheries policy in Aceh's northern to be implemented is Improving coordination between related institutions by involving local fishing communities and Development of fishing vessels and fishing gear that is efficient, effective and environmentally.
\end{abstract}

Keywords: adat laot law, policy, utilization.

\section{PENDAHULUAN}

Provinsi Aceh dikenal mempunyai sumberdaya pesisir dan laut yang melimpah. Luas wilayah perairan laut Aceh sekitar $295.370 \mathrm{~km}^{2}$. Ekosistem laut di sepanjang pesisir Aceh sangat sesuai bagi 
kehidupan, biota laut. Kondisi yang demikian sangat strategi untuk usaha perikanan, khususnya penangkapan ikan di laut (DKP 2010). Kondisi wilayah tersebut menjadikan Provinsi Aceh sebagai salah satu wilayah yang memiliki potensi kelautan dan perikanan yang cukup besar. Dengan sentuhan teknologi yang lebih modern dan tepat guna menggantikan teknologi sederhana/tradisional yang masih ada, maka sektor ini mempunyai peluang besar dan dapat menjadi sektor dominan dan andalan untuk mengangkat serta meningkatkan pendapatan (income generating) dan kesejahteraan masyarakat Aceh di masa depan.

Sumberdaya ikan pada umumnya mempunyai sifat "open access" dan "common property" yang artinya pemanfaatan bersifat terbuka oleh siapa saja dan kepemilikannya bersifat umum. Masalah common property right memang menjadi masalah klasik dalam pemanfaatan sumberdaya perikanan. Masalah tersebut dengan kondisi open access mengakibatkan semua orang merasa memiliki, semua orang bisa mengakses, dan eksternalitasnya ditanggung bersama sehingga dapat merusak kelestarian sumber daya alam (Sulaiman 2010). Salah satu konsep pengelolaan yang secara tegas disebutkan dalam Pasal 6 UU Perikanan adalah perlunya "mempertimbangkan hukum adat dan/atau kearifan lokal" serta memperhatikan peran serta masyarakat. Namun kearifan lokal dalam hal ini tidak boleh bertentangan dengan hukum nasional.

Hukum adat laot ini merupakan bentuk kearifan lokal yang tumbuh dari komunitas masyarakat Aceh. Kearifan lokal dalam bentuk hukum adat laot seisinya tidak bertentangan dengan kebijakan pemerintah daerah. Panglima Laot tahun 2001 merumuskan bahwa hukum adat laot adalah "hukumhukum adat yang diberlakukan oleh masyarakat nelayan untuk menjaga ketertiban dalam penangkapan ikan dan kehidupan masyarakat nelayan di pantai.

Hukum adat laot tersebut berkaitan dengan beberapa pengaturan, yang meliputi aturan tentang penangkapan ikan, bagi hasil, sewa menyewa, pengupahan dan sebagainya, wilayah khusus tempat penambatan perahu/pukat pantai, tempat penjemuran alat penangkapan ikan/memperbaiki kerusakankerusakan baik alat penangkapan ikan maupun perahu larangan melakukan kegiatan di laot/pantang laot, penemuan harta di laot, upah atau pengganti jerih payah panglima laot dan atau pawang, pertengkaran/perselisihan/ pertikaian dan perkelahian di laot, perusakan lingkungan laot, tentang pencurian ikan di laot, kecelakaan di laot, dan aturan-aturan laot yang berhubungan dengan semua kegiatan mencari nafkah di laot (Nyak Pha 2001).

Kearifan lokal belum sepenuhnya dipertimbangkan dalam rangka pemanfaatan daerah penangkapan ikan di perairan utara Aceh. Pada sisi lain, kebijakan pemerintah juga masih jarang terdengar yang khusus mengatur pemanfaatan daerah penangkapan ikan. Dengan demikian diperlukan suatu kajian interaksi kebijakan perikanan tangkap dan kearifan lokal dalam pemanfaatan daerah penangkapan ikan. Pendekatan yang baik dalam mewujudkan pengelolaan perikanan tangkap yang bertanggung jawab dengan mengajak pihak-pihak yang berkepentingan untuk ikut berpartisipasi dalam mengembangkan pemahaman yang sama terhadap strategi kebijakan, sehingga nilai-nilai kearifan lokal dapat diakomodasikan dengan baik dalam regulasi ataupun perencanaan dalam pemanfaatan sumberdaya ikan. Tujuan dari penelitian ini adalah untuk menganalisis keterkaitan kearifan lokal (hukum adat laot) dengan kebijakan pemerintah di perairan utara Aceh dan menentukan strategi pemanfaatan daerah penangkapan ikan yang berbasis pada kearifan lokal.

\section{METODE PENELITIAN}

Penelitian ini dilaksanakan di perairan Utara Propinsi Aceh yang meliputi Krueng Aceh, Banda Aceh dan Krueng Raya, Kabupaten Aceh Besar. Penelitian ini dilaksanakan dalam dua tahap yaitu: tahap pertama survei lapangan tempat lokasi penelitian pada bulan Desember 2014, tahap kedua pengumpulan data lapangan pada bulan Februari-April 2015. Data yang digunakan dalam penelitian ini adalah data primer dan data sekunder. Data primer diperoleh melalui pengamatan langsung atau survei di lapangan. Selain pengamatan langsung (survei), data primer juga diperoleh melalui wawancara 
mendalam terhadap berbagai stakeholder. Kelompok stakeholder meliputi nelayan, panglima laôt, pengelola pangkalan pendaratan ikan (PPI), Dinas Kelautan dan Perikanan dan pedagang ikan. Data sekunder diperoleh dari instansi terkait seperti Lembaga Panglima Laot Aceh, Dinas Kelautan dan Perikanan serta laporan hasil-hasil penelitian.

Data yang dikumpulkan dalam penelitin ini dilakukan untuk mengetahui kondisi umum pemanfaatan daerah penangkapan ikan di perairan Utara Aceh, persepsi dan tanggapan nelayan terhadap kebijakan perikanan tangkap, lokasi penangkapan ikan, aktor yang terlibat, peraturan perundang-undangan yang berlaku di daerah penelitian, serta kelembagaan panglima laot. Eksistensi hukum adat laot dengan Kebijakan pemerintah dalam pemanfaatan daerah penangkapan ikan dianalisis menggunakan metode analisis deskriptif. Metode ini digunakan untuk menganalisis semua bentuk komunikasi, baik surat kabar, berita radio maupun semua bahan- bahan dokumentasi yang lain tentang kelembagaan Panglima Laot, untuk memberikan gambaran tentang peranan Panglima Laot sebagai pemangku hukum adat laot (kearifan lokal) dalam pemanfaatan sumberdaya ikan di perairan utara Aceh (Hasan 2002). Sedangkan strategi kebijakan perikanan tangkap berbasis kearifan lokal di analisis menggunakan SWOT.

Analisis SWOT digunakan untuk menentukan berbagai opsi strategi kebijakan perikanan tangkap dalam pemanfaatan daerah penangkapan ikan. Pada prinsipnya, penentuan ini dilakukan dengan mempertimbangkan berbagai aspek kesesuaian/kriteria yang ada dan beberapa hal yang menjadi faktor pembatasnya di perairan Utara Aceh. Terdapat beberapa langkah yang dilakukan dalam analisis SWOT, diantaranya adalah: (1) identifikasi Faktor internal dan faktor eksternal; (2) Internal Factor Analysis Summary (IFAS); (3) External Factor Analysis Summary, (4) Alternatif strategi hasil SWOT.

\section{HASIL DAN PEMBAHASAN}

\section{Sistem Kelembagaan Panglima Laot}

Dalam menjalankan tugas dan fungsinya, Panglima Laot memiliki sistem kelembagaan yang mengatur tentang ketertiban masyarakat nelayan dalam hal penangkapan ikan, pemeliharaan sumberdaya ikan, serta menjaga ketentraman hidup masyarakat nelayan di wilayah tersebut. Kearifan lokal merupakan identitas yang sangat menentukan harkat dan martabat manusia dalam komunitasnya. Jenis kearifan lokal meliputi kelembagaan, nilai-nilai adat, serta tata cara dan prosedur. Sistem kelembagaan hak ulayat laut dalam panglima laot, yaitu: batasan wilayah pengelolaan, sistem aturan, sistem sanksi dan legalitas.

\section{Peranan Hukum Adat Laot dalam mewujudkan Perikanan Berkelanjutan}

Panglima Laot adalah seorang pemimpin nelayan yang secara hukum adat laot bertugas mengkoordinasi satu atau lebih wilayah operasional nelayan dan minimal satu pemukiman. Dalam melaksanakan fungsinya Panglima Laot memiliki wewenang sesuai dengan tingkatan dan hirarkhinya. Tugas Panglima Laot di antaranya: (1) memelihara dan mengawasi ketentuan-ketentuan hukum adatistiadat (2) mengkoordinasikan dan mengawasi setiap usaha penangkapan ikan di laut (3) menyelesaikan perselisihan/sengketa yang terjadi di antara sesama anggota nelayan atau kelompoknya (4) peranan dalam menyelenggarakan upacara adat laot (5) peranan dalam menjaga/mengawasi pohonpohon di tepi pantai (6) penghubung antara nelayan dengan pemerintah dan Panglima Laot.

\section{Interaksi Kebijakan Hukum Nasional dengan Lembaga Panglima Laot}

Hukum adat laot/kearifan lokal sudah ada sejak lama di Aceh dan terus berkembang bersamaan dengan tumbuhnya kebudayaan masyarakat adat nelayan di Aceh. Hukum adat laot/kearifan lokal tetap dipatuhi tanpa ada paksaan dan dijalankan sesuai dengan nilai budaya, norma-norma adat sesuai dengan syariat Islam oleh masyarakat adat nelayan di Aceh pada saat itu. Keberadaan hukum adat laot/kearifan 
lokal di Aceh diakui oleh hukum nasional, yang merupakan hukum yang berlaku di Indonesia. Beberapa peraturan mengenai pengakuan hukum nasional terhadap keberadaan hukum adat laot/kearifan lokal berkaitan dengan pengelolaan sumberdaya perikanan di Aceh sebagai berikut:

1. Undang Nomor 45 Tahun 2009 tentang Perubahan Undang-Undang Nomor 31 Tahun 2004 tentang Perikanan juncto Undang-Undang No. 31 Tahun 2004 tentang Perikanan

2. Undang-undang Nomor 27 Tahun 2007 tentang Pengelolaan Wilayah Pesisir dan Pulau pulau Kecil

3. Undang-undang Nomor 11 Tahun 2006 tentang Pemerintahan Aceh

4. Undang-undang Nomor 32 tahun 2004 Tentang Pemerintahan Daerah

5. Qanun Nomor 16 Tahun 2002 Tentang Pengelolaan Sumberdaya Kelautan dan Perikanan

6. Qanun Aceh Nomor 9 Tahun 2008 Tentang Pembinaan Kehidupan Adat Istiadat

7. Qanun Aceh Nomor 10 Tahun 2008 Tentang Lembaga Adat

Berdasarkan peraturan perundang-undangan di atas, diketahui bahwa hukum adat laot sudah diakui di dalam hukum nasional sejak dahulu dan sekarang kekuatan hukum adat laut terlihat lebih kuat. Hal ini dapat terlihat dari adanya hukum nasional yang memuat tentang hukum adat laot. Hukum nasional berfungsi untuk melindungi keberadaan hukum adat di Aceh termasuk hukum adat laot. Hukum adat laot tersebut merupakan hukum yang tidak tertulis dalam lembar pengesahan negara, namun tetap dipatuhi oleh masyarakat adat nelayan karena merupakan suatu kesepakatan bersama. Pemerintah Aceh juga memberikan fasilitas untuk terus membina dan mengembangkan hukum adat laot di Aceh.

\section{Keterkaitan Panglima Laot dengan Lembaga Lain}

Panglima Laot dalam melaksanakan pemanfaatan kebijakan perikanan tangkap bekerja sama dengan Dinas Kelautan dan Perikanan, Syahbandar dan polisi perairan. Segenap fungsionaris Lembaga Adat laot mendapat bimbingan dari Dinas Kelautan dan Perikanan, baik mengenai teknologi penangkapan hasil laut maupun dalam pelaksanaan peraturan pemerintah, terutama yang menyangkut pengelolaan lingkungan laut seperti pemilikan jaring yang tidak merusak lingkungan dan daerah penangkapan ikan. Keterkaitan panglima laot dengan lembaga lain sangat berdampak positif pada kehidupan masyarat nelayan. Dalam hukum adat laot telah dikembangkan sistem pelaporan untuk menjaga lingkungan laut. Jika seorang nelayan atau anggota masyarakat lainnya melihat ada oknum yang melanggar lingkungan hidup, maka pelanggaran tersebut harus dilaporkan segera pada Panglima laot atau kepada pihak yang berwajib. Panglima Laot secara kelembagaan mengatur pengelolaan lingkungan laut dengan aturan selain memuat larangan juga mengatur cara orang bertindak terhadap lingkungan dalam lingkup yang terbatas sesuai dengan kewenangan yang dimilikinya. Pengaturan seperti itu membawa konsekuensi lebih efektifnya berlaku hukum atas pengelolaan lingkungan laut di wilayah Aceh.

\section{Upaya Penyelesaian Kebijakan Pemanfaatan DPI Berbasis Kearifan Lokal}

Pemanfaatan sumberdaya perikanan dari waktu ke waktu terus mengalami peningkatan, seiring dengan berkembangnya teknologi. Begitu juga dengan teknologi yang berkenaan dengan penangkapan ikan. Daerah penangkapan ikan merupakan tempat terjadinya interaksi antara alat tangkap yang digunakan untuk menangkap dengan sumberdaya ikan target tangkapan. Apabila dalam suatu perairan terdapat banyak sumberdaya ikan tapi alat tangkap tidak bisa dioperasikan dikarenakan suatu faktor tertentu maka daerah tersebut tidak bisa dikatakan sebagai daerah penangkapan ikan (Diyanto 2009). Daerah penangkapan ikan sebaiknya dipilih pada daerah yang mempunyai akses yang bagus untuk ruaya ikan, sehingga ikan dapat dengan bebas datang dan pergi baik dalam bentuk gerombolan.

Dalam menentukan strategi kebijakan pemanfaatan DPI, maka perlu digunakan suatu analisis untuk mengambil keputusan mengenai kebijakan perikanan tangkap yang berbasis kearifan lokal. Sebelum melaksanakan proses pengambilan keputusan yang layak untuk suatu kasus, terlebih dahulu 
dilakukan analisis terhadap faktor-faktor internal dan eksternal yang mempengaruhinya. Dalam kondisi yang ada saat ini yang populer digunakan adalah Analisis SWOT. Analisis SWOT digunakan untuk menentukan prioritas berbagai opsi kebijakan pemanfaatan daerah penangkapan ikan. Menurut Rangkuti (2005) menyatakan bahwa analisis SWOT pada umumnya digunakan untuk menidentifikasikan berbagai faktor secara sitematis untuk merumuskan strategi perusahaan.

\section{Faktor Strategi Internal dan Eksternal}

1. Faktor internal

Faktor internal yang diperoleh bersumber dari identifikasi kekuatan dan kelemahan yang diperoleh selama penelitian yang selanjutnya dituangkan dalam matriks Internal Factor Analysis Strategic (IFAS). Kisaran bobot yang digunakan berkisar antara 0,0 -1,0 (Tripomo dan Udan 2005). Berdasarkan hasil identifikasi survey lapangan, faktor-faktor tersebut dijabarkan sebagai berikut:

a. Strengths (kekuatan)

- Memiliki lembaga Panglima Laot yang terpercaya dalam pemanfaatan perikanan tangkap (S1)

- Tersedianya nilai-nilai kearifan lokal yang sifatnya mengikat setiap masyarakat nelayan dan selalu dipatuhi oleh setiap masyarakat nelayan, apabila terjadi pelanggaran terhadap aturan-aturan kearifan lokal akan terkena sanksi (S2)

- Usaha penangkapan ikan secara umum masih sangat menguntungkan (S3)

- Pengalaman nelayan dalam kegiatan perikanan tangkap cukup tinggi, yaitu rata-rata diatas 10 tahun (S4)

b. Weaknesses (kelemahan)

- Kurangnya penyuluhan tentang penangkapan untuk nelayan (W1)

- Panglima Laot Tidak melakukan patroli terhadap nelayan (W2)

- Sistem distribusi ikan yang masih kurang berjalan dengan baik (W3)

- Alat komunikasi di laut yang jangkauannya masih sangat terbatas (W4)

Tabel 1 Matriks IFAS pemanfaatan perikanan tangkap berbasis kearifan lokal

\begin{tabular}{lccc}
\hline \multicolumn{1}{c}{ Kekuatan } & Bobot & Rating & Skor \\
\hline Memiliki lembaga paglima laot & 0,17 & 3 & 0,51 \\
$\begin{array}{l}\text { Tersedia nilai-nilai keraifan lokal } \\
\text { Usaha penangkapan ikan masih }\end{array}$ & 0,18 & 3 & 0,54 \\
$\begin{array}{l}\text { menguntungkan } \\
\text { Pengalaman nelayan tinggi }\end{array}$ & 0,15 & 3 & 0,45 \\
$\begin{array}{l}\text { Subtotal } \\
\quad \text { Kelemahan }\end{array}$ & 0,17 & 3 & 0,51 \\
\hline $\begin{array}{l}\text { Kurangnya penyuluhan pada } \\
\text { nelayan }\end{array}$ & 0,08 & 2 & 2,02 \\
$\begin{array}{l}\text { Panglima laot tidak melakukan } \\
\text { patroli terhadap nelayan }\end{array}$ & 0,08 & 2 & 0,17 \\
$\begin{array}{l}\text { Sistem distribusi ikan masih kurang } \\
\text { Jangkauan alat komunikasi masih } \\
\text { terbatas }\end{array}$ & 0,09 & 2 & 0,17 \\
$\begin{array}{l}\text { Subtotal } \\
\text { Total }\end{array}$ & 0,06 & 1 & 0,18 \\
\hline
\end{tabular}


Berdasarkan Tabel 1 menjelaskan bahwa faktor dengan nilai tertinggi yaitu faktor tersedia nilainilai kearifan lokal adalah 0,54 poin. Untuk faktor nilai terendah yaitu jangkauan alat komunikasi masih terbatas sebesar 0,06 poin. Berdasarkan nilai Internal strategic Factors Analysis Summary (IFAS). diketahui bahwa kebijakan pemanfaatan perikanan tangkap berbasis lokal memiliki skor IFAS 2,61 $\geq$ 2.5, artinya kondisi internal memiliki kekutan untuk mengatasi situasi kelemahan. Hal ini bearti bahwa faktor-faktor internalnya berada di atas taraf rata-rata. Kondisi perikanan tangkap di perairan utara Aceh memiliki lebih banyak kelemahan yang harus diatasi agar dapat meraih peluang dengan memanfaatkan kekuatan yang dimiliki dalam pemanfaatan perikanan berbasis kearifan lokal, seperti harus sering melakukan kegiatan penyuluhan kepada nelayan agar para nelayan memahami cara menangkap ikan yang ramah lingkungan serta lebih sering para stekholder melakukan patroli untuk mengetahui kegiatan nelayan setiap hari di wilayah perairan utara Aceh.

2. Faktor eksternal

Berdasarkan hasil identifikasi survey lapangan, faktor-faktor eksternal (peluang dan ancaman) dijabarkan sebagai berikut:

a. Opportunities (peluang)

- Potensi pasar cukup besar akan sumberdaya perikanan (O1)

- Kebutuhan ikan laut untuk masyarakat meningkat (O2)

- Keinginan masyarakat untuk maju dalam usaha perikanan (O3)

- Rencana untuk mengganti kapal traditional ke kapal yang modern (O4)

b. Threats (ancaman)

- Harga BBM tinggi. Kenaikan harga BBM menyebabkan ada nelayan yang tidak dapat melaut (T1)

- Penurunan stok sumberdaya ikan(T2)

- Masuknya kapal-kapal luar ke wilayah perairan Aceh (T3)

- Harga ikan yang tidak stabil (T4)

Tabel 2 Matriks EFAS pemanfaatan perikanan tangkap berbasis kearifan lokal

\begin{tabular}{lccc}
\hline \multicolumn{1}{c}{ Kekuatan } & Bobot & Rating & Skor \\
\hline Potensi pasar yang besar & 0,17 & 4 & 0,71 \\
Kebutuhan ikan laut meningkat & 0,18 & 3 & 0,55 \\
Keinginan masyarakat untuk maju & 0,13 & 3 & 0,39 \\
dalam usaha perikanan & 0,14 & 3 & 0,42 \\
Rencana ganti kapal tradisional & & & 2,07 \\
Subtotal & & & \\
\hline \multicolumn{1}{c}{ Kelemahan } & 0,09 & 2 & 0,19 \\
\hline Harga BBM tinggi & 0,11 & 1 & 0,11 \\
Penurunan stok sumberdaya ikan & 0,07 & 1 & 0,07 \\
Masuknya kapal-kapal luar & 0,07 & 1 & 0,07 \\
Harga ikan yang tidak stabil & & & 0,44 \\
Subtotal & 1,00 & & 2,61 \\
\hline Total &
\end{tabular}

Tabel 2 diatas menunjukkan faktor dengan nilai tertinggi adalah potensi pasar yang cukup besar adalah 0,71 poin. Untuk faktor nilai terendah yaitu masuknya kapal luar ke perairan Aceh dan harga kan yang tidak stabil sebesar 0,07 poin. Nilai rata-rata skor yang didapat dari strategi eksternal sebesar 2,51 poin. Hal ini menunjukkan bahwa kondisi ekternal kebijakan pemanfaatan perikanan tangkap berbasis kearifan lokal di perairan utara Aceh berada pada taraf rata-rata. Ancamannya memiliki nilai 
lebih besar dibandingkan dengan peluang yang dapat diraih. Hal yang perlu dilakukan adalah menguatkan internal oleh instansi terkait untuk mempersiapkan mengatasi ancaman yang ada, seperti masuknya kapal-kapal luar ke wilayah aceh serta harga ikan yang tidak stabil, kondisi ini sangat memerlukan kerja keras semua pihak untuk mereduksi keadaan sehingga dalam pemanfaatan perikanan berbasis kearifan lokal dapat dilakukan secara efektif.

Matriks IFAS dan EFAS menunjukkan, kondisi kebijakan pemanfaatan daerah penangkapan ikan berbasis kearifan lokal di perairan utara Aceh masih terjaga nilai-nilai kearifan lokal dan tingkat teknologi penangkapan ikan sudah mengalami peningkatan. Pembatas-pembatas ini merupakan faktor koreksi dalam memenuhi kriteria-kriteria pengembangan sehingga kebijakan pemanfaatan sumberdaya ikan berbasis kearifan lokal yang dipilih benar-benar merupakan kebijakan terbaik.

Hasil perhitungan selisih total skor diperoleh kooordinat $(1,43 ; 1,63)$ yang terletak pada kuadran I (mendukung strategi agresif). Posisi pada kuadran I mengindikasikan bahwa strategi kebijakan pemanfaatan perikanan tangkap di perairan utara Aceh memiliki kekuatan dan peluang yang dapat dimanfaatkan untuk mendukung kebijakan pengembangan secara agresif. Diagram cartesius SWOT kebijakan pemanfaatan perikanan tangkap di perairan utara Aceh dapat dilihat pada Gambar 1.

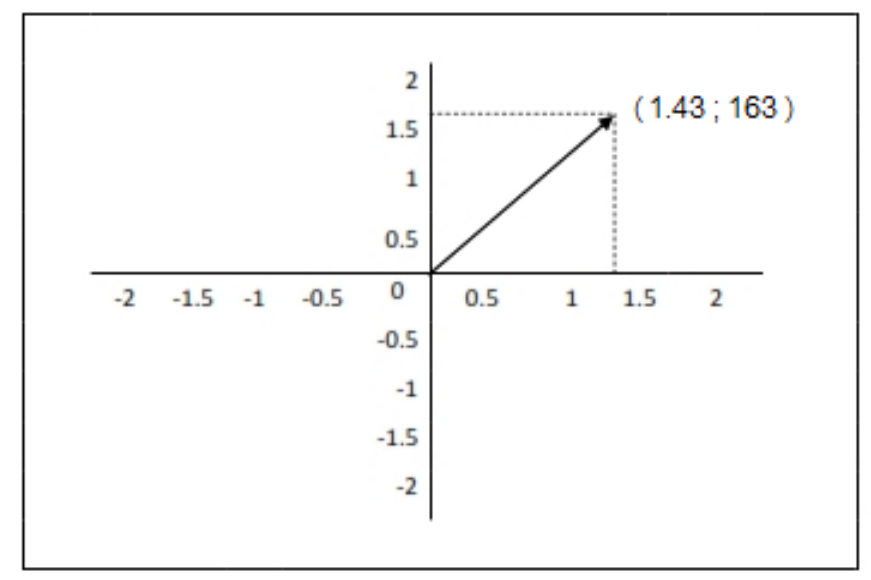

Gambar 1 Diagram cartesius SWOT

Berdasarkan Diagram Cartesius SWOT (Gambar 1), maka strategi yang digunakan adalah strategi S-O yaitu Strategi yang disusun dengan menggunakan seluruh kekuatan dan peluang yang dimiliki. Beberapa strategi yang dapat di ambil antara lain:

- Meningkatkan koordinasi antara institusi terkait dengan melibatkan masyarakat sekitar. Strategi ini diambil dengan pertimbangan bahwa kelembagaan panglima laot dalam mengambil kebijakan perikanan di Aceh tentunya harus didukung dan ditaati oleh seluruh stekholder yang berperan dalam kegiatan perikanan. Nelayan diharapkan mampu mengembangkan kelembagaannya guna mempermudah pemerintah dalam mendata, memberikan penyuluhan serta memberikan subsidi agar semua nelayan mendapatkan jatah yang sama dan tak luput dari pembagian subsidi tersebut.

- Meningkatkan teknologi yang lebih modern dalam pemanfaatan sumberdaya ikan yang disesuaikan dengan nilai-nilai kearifan lokal. Strategi ini diambil dengan pertimbangan bahwa potensi sumberdaya perikanan di Aceh masih banyak yang belum dimanfaatkan secara optimal, dimana nelayan di Aceh masih sangat kurang dalam memanfaatkan teknologi. Sehingga pemerintah harus lebih memperhatikan kondisi perikanan tangkap secara umum di perairan utara Aceh dengan cara melengkapi fasilitas-fasilitas yang masih kurang, membangun sarana dan prasarana, menyediakan teknologi penangkapan yang ramah lingkungan, dan lain sebagainya. Dengan adanya perhatian pemerintah tersebut, diharapkan kondisi perikanan 
tangkap di Perairan utara Aceh akan maju dan berkembang sehingga masyarakat nelayan akan sejahtera.

\section{KESIMPULAN DAN SARAN}

\section{Kesimpulan}

Berdasarkan hasil penelitian, dapat disimpulkan:

1. Panglima Laot merupakan kelembagaan masyarakat adat yang tertua di Indonesia, bergerak dalan bidang perikanan. Lembaga ini sudah mendapatkan pengakuan hukum positif, baik dari pemerintah pusat maupun pemerintah Aceh. Nilai-nilai yang terkandung dalam hukum adat Laot (kearifan lokal) sangat didukung, dan dijalankan oleh setiap nelayan yang ada di perairan utara Aceh.

2. Prioritas utama strategi kebijakan perikanan tangkap berbasis kearifan lokal adalah peningkatan kapasitas kelembagaan Panglima Laot sebagai pemangku adat Laot (kearifan lokal), serta pengembangan kapal perikanan dan alat penangkap ikan yang efisien, efektif, dan ramah lingkungan.

\section{Saran}

Setiap kebijakan pembangunan perikanan tangkap hendaknya selalu melibatkan partisipasi seluruh stakeholder khususnya masyarakat nelayan, baik dalam perumusan maupun implementasinya. Dengan demikian, masyarakat atau nelayan merasa ikut bertanggung jawab atas keberhasilan implementasi kebijakan tersebut.

\section{DAFTAR PUSTAKA}

[DKP] Dinas Kelautan dan Perikanan. 2010. Statistik Perikanan Tangkap Provinsi Aceh: Banda Aceh. Banda Aceh (ID): Dinas Kelautan dan Perikanan. 24 hal.

Hasan M. I. 2002. Pokok Pokok Materi Metodologi Penelitian dan Aplikasinya. Jakarta (ID): Ghalia Indonesia. 154 hal.

Diyanto M. 2009. Strategi Pengembangan Perikanan Tangkap dalam Meningkatkan Ekonomi Masyarakat Pesisir di Kabupaten Lampung Barat. [disertasi]. Bogor (ID): Institut Pertanian Bogor.

Nyak Pha M. H. 2001. Panglima Laot: Peranannya dalam Lembaga Adat Laot. Makalah Duek Pakat Panglima Laot se-Aceh di Sabang. Aceh (ID): 19-20 hal.

Rangkuti F. 2005. Analisis SWOT Teknis Membedah Kasus Bisnis. Jakarta (ID):

Gramedia Pustaka Utama. 188 hal.

Sulaiman S. 2010. Tantangan pengelolaan perikanan di Indonesia. Kanun: Jurnal Ilmu Hukum, 12(3), 515-542 hal.

Tripomo T, Udan. 2005. Manajemen Strategi. Bandung (ID): Rekayasa Sains. 117 hal. 